TITLE:

\title{
The New Face of Debt-Peonage in the Bolivian Amazon: Social Networks and Bargaining Instruments
}

\section{$\operatorname{AUTHOR}(\mathrm{S})$ :}

Cardona, Walter Cano; De Jong, Wil; Boot, René G. A.; Zuidema, Pieter A.

\section{CITATION:}

Cardona, Walter Cano ...[et al]. The New Face of Debt-Peonage in the Bolivian Amazon: Social Networks and Bargaining Instruments. Human Ecology 2014

ISSUE DATE:

2014-05-20

URL:

http://hdl.handle.net/2433/188739

\section{RIGHT:}

The final publication is available at link.springer.com; 許諾条件により 本文は2015-05-21に公開.; この論文は出版社版でありません。引用の 際には出版社版をご確認ご利用ください。; This is not the published version. Please cite only the published version. 


\title{
THE NEW FACE OF DEBT-PEONAGE IN THE BOLIVIAN AMAZON: SOCIAL NETWORKS AND BARGAINING INSTRUMENTS
}

\author{
WALTER CANO CARDONA \\ Center for International Forestry Research, Bolivia and Utrecht University, Netherlands
}

WIL DE JONG

Center for Integrated Area Studies, Kyoto University, Japan

RENE BOOT

Tropenbos International and Utrecht University, Netherlands

PIETER ZUIDEMA

Wageningen University and Utrecht University, Netherlands

\begin{abstract}
The debt-peonage system is an agreement between patrons and laborers in different economic activities worldwide. A common feature is social exploitation of laborers that generate profits to the patrons. In recent literature it has been argued that debt-peonage can be an economically sound arrangement that secures the needs of actors. The paper evaluates to what extent traditionally strong debt-peonage in forest-dwelling communities in the Bolivian Amazon, has developed in a way that better secures the needs and economic interest of multiple actors. Case studies in sixteen communities yielded qualitative information on debt relations between peasants, traders and former patrons. Debt-peonage changed from a mechanism to provide and keep workforce indebted to new social relationships, equitable commercial links, opportunity to access work capital and production chain diversification. This rapid shift was caused by important changes in land and forest regulations.
\end{abstract}

Keywords: habilito, Brazil nuts, community forestry, land reforms, forest policy reforms, barraca

\section{INTRODUCTION}

Debt-peonage is a form of labor agreement still in use worldwide today. The practice is rooted in the social, cultural and economic heritage in some countries (Barham and Coomes 1994a, Stackley 1999). Debt-peonage is seen by many scholars as a perverse form of social subjugation and exploitation. The practice was reported in the Amazon basin during the rubber boom (Assies 2002, Burberi 2007, Fifer 1970, da Cunha 1957), in Central America on post-colonial haciendas (Brown 2003, Meyers and Carlson 2002, Parrish 1982), in New Mexico in the arrangements between the Spanish-speaking population and the English-dominant society (Knowlton 1962) and in India on the estates that remained from the colonial period (Bhandari 2009).

The authors cited above mostly considered debt-peonage as a form of inhuman treatment, but others interpreted it as: social relations of pre-capitalist production (Weinstein 1986), livelihood strategies based on power imbalances between oppressor and oppressed (Brown 2006, Knight 1986), a relatively effective mechanism to leverage resources difficult to access, or an efficient 
type of contract given certain work conditions (Barham and Coomes 1994b). A common element among these different interpretations is its importance to provide for and control workers, according to the requirements of productive activities where labor was needed (Bales 2000, MacDonald and McWhiney 1980, Washbrook 2006).

In all cases where debt-peonage persists it has elements of individual and collective decisionmaking but entails subjugation imposed by a powerful group in response to a workforce's needs and the opportunities of alternative work available. The acceptance of debt peonage is based on the comparative advantages that this means in terms of the worker's welfare (Bauer 1979, Knight 1988, Martinez-Alier 1977), influenced by the type of relation between laborer and patron. For instance, in Central America, peasant resistance to wage labor was the answer to their preference for a feudal system (Knight 1986). In the Amazon basin during the rubber boom, people accepted debt-peonage to retain the advantages of individual work autonomy characteristic of an extractive model (Barham and Coomes 1994b, Weinstein 1986). In the northern Amazon region of Bolivia during the barraca or Brazil nut estate period, debt peonage was seen as a necessary condition to initiate productive work in the field (Bojanic 2001), but also as a way to access credit and reduce transaction costs of extracting and transporting the harvested product (Barzel 1989, Barham and Coomes 1994b, 1994c, Stoian 2006).

In the northern Bolivian Amazon, debt-peonage, locally called 'habilito' evolved particularly among social actors linked to the productive sectors of rubber, Brazil nut and timber, modifying the levels of dependency between them. Before the second agrarian reform in Bolivia during 1990s, habilito allowed patrons to attract workers and ensure their permanence on the barracas under conditions controlled by the employer. The second agrarian reform, however, transferred property rights of land and natural resources, including over areas of former Brazil nut estates, from patrons to communities. Since then forest dwellers have greater decision capacity over the use of valuable forest resources, which also allows them to negotiate more favourable terms for the sale of these resources and more favourable loan conditions. As a consequence, habilito in the region has become a mechanism to negotiate access to resources where the new form of ownership requires new forms of negotiation.

The current use of habilito in northern Bolivia raises some fundamental questions of debtpeonage as a labor negotiation and contracting tool. The classical definition of debt-peonage is the payment of a loan with the labor or services of the debtor (Bauer 1979, Knight 1986, 1988, Washbrook 2006). The typical case of debt-peonage is that both capital and assets requiring labor are monopolized by one party, allowing that party to establish the conditions of compensation for work services provided. However, what happens in the case entrepreneurs intend to use the mechanism of debt-peonage when they do not control the same assets (Rutledge 1975)? What happens when one of the engaging parties controls capital, and the other the labor and the productive assets that require labor? How do early forms of debt-peonage change among former employers and employees when a new regime of property rights replaces an old arrangement where debt-peonage was common? To what extent do these actors who previously accepted debts learn to use their new rights in negotiations in debt-peonage arrangements? The answers to these questions are the innovations that characterize the evolution of habilito in the northern Bolivian Amazon, following the regulatory changes that started since the mid-1990s. 
This paper consists of seven sections including this introduction. Section 2 describes the methods used to collect and analysis data and the research area. Section 3 analyses debt-peonage during the time of rubber exploitation, and the role it acquired during changes of social relations and the emergence of independent peasant communities. It also reviews the contemporary function of habilito in the livelihoods of the rural population and the influence of habilito on trade relationships, power and cash flows into communities that engage in Brazil nut production. It furthermore analyses the benefits of habilito in the Brazil nut production chain. Section 5 discusses the findings emphasizing the most important aspects of the new culture of habilito from a local and international perspective and section 6 concludes.

\section{MATERIALS AND METHODS}

We conducted research in sixteen rural communities located in the departments of Pando and Beni in the northern Bolivian Amazon. Communities that engage in habilito in the northern Bolivian Amazon are mostly characterized as mestizo settlements (Fuentes et al. 2005). These communities are the result of resettling of the mixed population that migrated into the region ever since the rubber boom started, late $19^{\text {th }}$ century. Initially the rural population of northern Bolivia that was part of the early rubber and Brazil nut sectors mostly lived inside barracas until the mid-1950s. Since then many barraca residents moved to independent communities, which developed as fairly autonomous villages that engage in agriculture and other tropical forest natural resource use, with different degrees of participation in the regional market economy. Other communities in the region only separated from barracas in more recent times, or they were abandoned by previous barraca owners since the mid-1990s land reforms. Over the last half century or so, but especially since the 1990s, the region has experienced much intra-regional migration (Stoian and Henkemans 2000, Stoian 2006). The region has a few sparse ethnic indigenous groups that these days own extensive areas of legally recognized indigenous territory, but they have much less engagement with the Brazil nut sector and were not included in our sample.

The sample of communities for research was randomly selected from among mestizo communities, using the basic criterion of dependency on non-timber forest resources, distinguishing between agro extractive and extractive communities (Stoian and Henkemans 2000). Based on our first initial survey, the sixteen communities were divided in those with high Brazil nut production and related labor demands and communities with lower Brazil nut production (Cano 2012) and we selected randomly eight communities of each category. We conducted semi-structured interviews with key informants who were long term permanent residents in their community, knowledgeable of community issues, but also involved in Brazil nut extraction. We also interviewed traders and barraca owners before, during and after the harvest season. We observed actual bargaining of habilito and sale of Brazil nuts between sellers and buyers. The above information was supplemented by informal interviews with representatives of NGOs operating in the region, obtaining a total of 171 in-depth interviews.

The interviews provided qualitative information on changes of social relations, and the dependency and changes of habilito since its early use until today. Analysis of the information focused on risk management in the negotiations of habilito, power relations in those negotiations and the use of ideological discourse to impose forms of repayment. It also focused on control of 
labor and the emergence of new labor arrangements. We collected data on income and expenditures channeled through habilito, and of number of transactions. We only focused on habilito transactions linked to communities in the region that engaged in Brazil nut collecting and trade.

\section{The northern Bolivian Amazon}

The northern Bolivian Amazon, which contains Pando and the Amazon region of Beni covers $86,261 \mathrm{~km}^{2}$ and has a population of 211,572 inhabitants in 2007 (INE 2007). The region is mostly covered with tropical rain forest with a natural abundance of Brazil nut (Bertholletia excelsa) and rubber (Hevea brasiliensis) (DHV 1993). The most important commercial economic activities today are the collection of Brazil nuts and timber extraction and trade in the regional towns and border regions. Social relations in the region were until recently based on the customs that governed life in the former barraca. These were forest extraction production units comprising of a forest estate and a workforce hat was tied to the estate through debt-peonage (Ruiz 2005, Stoian 2006).

Brazil nut extraction was until recently the main source of cash among the region's rural inhabitants, more recently complemented with income from timber sales. Agriculture, hunting and fishing are mostly for household consumption although they contribute to cash income in communities near major urban centres (Zenteno 2012). Mestizo communities in the region divide into agro-extractive communities, i.e. those that depend to a larger degree on agriculture and extractive communities, i.e. those that depend more on Brazil nut extraction and timber) (Stoian and Henkemans 2000, Zenteno et al. 2013, de Jong et al. 2013).

Since the late 1980s, Brazil nut extraction became the only non-timber forest product industry in the region, and this was soon followed by far reaching decentralization of the national government, forest legislation reform and a second agrarian reform (de Jong et al. 2006). As a result, rural settlements many of which were located inside old barracas acquired for the first time legal status and acquired formal title over their lands (Pacheco 2006). The new forestry law of 1996 changed access rights to forests, bestowing peasants and indigenous people the exclusive right of forest exploitation over land that had legally become theirs (Forest Law No. 1700). However, habilito practices and some forms of social relations characteristics of the barraca in previous times largely continued as before (del Pilar-Gamarra 2007). The reform process described above triggered a reallocation of rights to access and use of forest resources and land, forging new ties of dependency and mutual cooperation among actors that are described in the following sections.

\section{THE EVOLUTION OF HABILITO IN NORTHERN BOLIVIA}

\section{Transition of habilito from the barraca to the community}

Habilito emerged during the boom of rubber extraction in the Amazon basin. In Bolivia it originated as a merger between coercive servitude in the west of the country and the customs of advanced payments during the period of quinine extraction in the northern Bolivia Amazon before the rubber boom (del Pilar-Gamarra 2007, Stoian 2006). Barraca workers maintained long daily work routines and had to buy at credit daily necessities at the company stores. 
Barraca owners set the prices for goods and forbid workers to practice agriculture on the estate (Stoian 2000).

After the definite decline of rubber production in northern Bolivia by late 1980s, many of the previous barraca residents migrated to the region's major towns, Cobija, Guayaramerin and Riberalta. Since the early 1990s international demand for Brazil nuts increased resulting in a resurgence of the barraca and the return of habilito (Stoian 2000). The organization of labor also changed as fewer workers reside inside the barracas and collectors migrate to the Brazil areas every year from late November and until early March. The means of production remained under the control of the patrons but there was a decrease of control that they held over forest workers who now lived in the major towns and independent communities (Henkemans 2001). Habilito was revitalized as it allowed patrons to control workers operating in the field. In this new period of the barraca - habilito organization of Brazil nut production, previous coercive means were replaced by an ideological discourse that helped to consolidate the bonds of dependency between forest workers and patrons (Barham and Coomes 1994a). This discourse was often reinforced by pseudo family ties, as patrons became godfathers of their workers' children (Lyons 2006). The socio-economic ties between patrons and forest workers transformed into a relationship of reciprocity, as it provided a sense of security to workers and ensured a steady supply of raw materials to the Brazil nut entrepreneurs. During this period, joining a Brazil nut extraction workforce and working under habilito arrangements was an individual decision enticed by the security offered to rural and peri-urban dwellers and their families. The concurrence of people who worked under a habilito arrangement and people who choose a different option confirms this (Henkemans 2000, Stoian 2006).

During the 1990s the Brazil nut production chain started with a private company who managed capital and the market. The second link was mostly of traders, and the last link constituted independent communities and Brazil nut collectors (Figure 1). This reflects a reduction of actors because the barraca was no longer a basic operative unit of forest product exploitation as in previous years (Pacheco 1992), but rather had become an area over which Brazil nut entrepreneurs held exclusive harvesting rights. This situation once again changed after the legal tenure reform that began in Bolivia during the mid-1990s and were implemented in the north into the 2000s. As a result, relations of subordination evolved to capitalist trade relations because the old Brazil nut collectors, who only could negotiate based on their control of their own labor, now could negotiate based on their control over forest areas with Brazil nut trees. Since then new opportunities of mutual benefit arose based on the negotiation of rights to access resource in exchange for capital and habilito also adapted to these new circumstances.

\section{Figure 1}

\section{Habilito in the livelihoods of forest dwellers}

Habilito nowadays plays an important role in the livelihoods of remote forest dwellers in northern Bolivia (Assies 1997) as it allows them to obtain consumables that are not otherwise available. However, there are several particularities of the Brazil nut extraction process that also explains the continuing use of habilito (McDonald and McWhiney 1980). At the beginning of the Brazil nut harvest in November a family's food reserves are limited. This period coincides 
with the completion of the planting season in northern Bolivia (DHV 1993) and products of the annual harvest are not available yet. Thus, the negotiations for advance payments start as requests for food and other daily necessities. The demands vary substantially depending on family needs. Families who manage their agricultural plots for continuous supply may reduce significantly the amount of goods they request as advance payment compared to more opportunistic food producers. The difference may range between US\$ 14 and US\$ 100 that a family receives at the beginning of the Brazil nut harvest (Zenteno 2012).

According to Zenteno (2012), 45 percent of a sample of 239 households had negotiated habilito during 2008, when the Brazil nut prices were one third of the value reported from the previous year (Table 1). The group that negotiated habilito obtained more than 31 percent of their rice consumption not from their own fields, had 21 per cent less agricultural crops, and owned 56 percent fewer pigs than families who did not rely on habilito (Table 1). On the other hand, in spite of the decrease of the Brazil nut price, the population with habilito collected 43 percent more Brazil nut boxes, had a 38 percent higher income from Brazil nut sales and 22 percent higher earnings from the sales of timber, than those without habilito (Table 1). Dependence on habilito continues as long as the receivers of habilito continue delivering the raw material that motivates the merchant to assume the risk of investing in habilito. The major volume of product gathered by families with habilito indicates that they indeed are complying with the terms of the agreement.

\section{Table 1 \\ Habilito in the commercial relations of forest dweller communities}

Nowadays, Brazil nut collection is carried out by people living in remote communities and by people residing in the peri-urban neighborhoods of Cobija, Riberalta and Guyaramerin, the region's major towns. Our data indicate that peri-urban residents can earn between \$US 1000 and \$US 2000, during a year with good Brazil nut prices when employed as Brazil nut collectors in communities or in the few areas that are still exploited as barraca. A rural family that controls 500 hectares of land (which is the effective area allocated to single families during Bolivia's latest land reform) can at a price of \$US 17 per box (price registered in 2009), obtain over \$US 2550 for 150 boxes of Brazil nut. Information obtained in 2008 on income from Brazil nut sales in communities with variable distance from urban centres (from $10 \mathrm{~km}$ to more than $100 \mathrm{~km}$ measured in hours of travel to the community), revealed the notable margin of benefits channeled through habilito, in spite of the low prices registered that year (Figure 2). According to this information, the price of Brazil nut tends to decrease when access to the community becomes more difficult, because of large distance or poor road connections. On the other hand, communities with this limitation can often compensate this by collecting larger volumes as they may have access to a larger number of Brazil nut trees (Zenteno et al. 2013).

Our findings suggest that nowadays community residents and peri-urban residents in northern Bolivia obtain economic surplus because of an interaction of three factors: (1) the increase of the Brazil nut price; (2) the change of habilito as an instrument to impose or accept debt and commitments to assure benefits, into an economic alternative option that is available even for people who do not reside in the forest, and (3) the reassignment of property rights over land and access to forest resources. 
We observed that the negotiation of habilito between community members and traders has changed. Currently traders cannot access the Brazil nut stocks belonging to communities if they fail to establish good relationships with community members. These relationships are largely channeled, using habilito as an incentive. If a trader has sufficient capacity to ensure habilito during the harvest season, the more likely he is to develop strong social and commercial ties with communities that control Brazil nut stocks. A trader has to be willing to provide habilito during periods of low Brazil nut prices, when expected benefits may be negative, and even out of the harvest season. Under such an agreement, the trader makes a risky investment in exchange for a monopoly access to Brazil nuts in a particular area.

We also observed cases in which traders established a working agreement with members of families who dominated communal economy and politics in eight communities of the total sample. The trader provided substantial amounts of cash or in kind as an advance payment to these dominant family members. The recipients reinvested these funds or goods among other community members, according to their own social rules. The dominant group captured benefits when transferring habilito interest to other community members. This transfer takes place more and less the same as in the early barraca system, selling overpriced consumables and paying less for the product. We call this mode "second-tier habilito", as the first-tier habilito is between the trader and dominant community members.

The benefits obtained by the dominant group have a cost. The dominant family members assume a commitment to control communal Brazil nut extraction and enforce the habilito in the community. The dominant family members are perceived by the rest of the community as the new patrons as they control both capital, but also strongly the rules of access to land and Brazil nut forests. The benefits, however, are significant. They pay between \$US 0,71 to US\$1,43 less for a single box that the traders to whom they resell the boxes. On average, dominant families annually gained \$US 10,700 for operating as habilito intermediaries. In addition to paying less for a box of Brazil nut, dominant family members may charge for the right to harvest Brazil nuts or demand a percentage of the harvest for themselves. In one community, dominant family members charged \$US 0.57 for a box of Brazil nut harvested, but which they did not buy themselves from community members. In another community they charged as a fee $10 \%$ of the total amount harvested. Opposition to these measures is usually punished by social exclusion from the community. Table 2 shows a classification of interviewees based on their capacity to collect Brazil nuts. The 'large producers' correspond to the dominant families within a community who obtain income from their own land and reselling Brazil nuts from other community which they obtained through the second-tier habilito. We observed dominant families controlling Brazil nut trade in communities in $25 \%$ of the studied communities. Dominant groups have more and expensive goods than the rest of the community members, enough money to have their kids studying in the regional towns or even own a house there (Zenteno et al. 2013).

\section{TABLE 2}

Dominant families who engage in second tier habilito default on deliveries or sell their harvest to a different trader than the one who provided the advance payment. They use these funds to have more capital to trade inside the own or neighboring communities. Debts that dominant families 
accumulate with traders are commonly compensated by exclusive access of the same traders to Brazil nut stocks within the community. The trader then acquired a virtual harvesting monopoly in exchange for flexibility or forgiveness of existing debts. Interviewees revealed that some traders may have unpaid debts of up to \$US 20.000 under such schemes.

\section{Habilito in the Brazil nut production chain}

The breakdown of the former barraca structure led to the reconfiguration of local powers and social relations, triggering the emergence of specializations in the Brazil nut production chain, and specific rules to regulate performance of each link. In addition to the reasons given above, this also explains why northern Bolivian forest dwellers continued to depend on habilito still controlled by the old patrons. It also partly explains why old patrons stopped their efforts to regain the power that gave them de facto tenure over land and valuable forest products. The adaptation of habilito to the new reality of the Brazil nut sector contributed to this diversification and specialization, and recognition of the importance of each actor. For example, peasants have always had the ability to undertake extractive activities. Under the new reality, however, traders and intermediaries, many of who were former patrons, developed the ability to trade. The change in property rights over land and forests forced these actors to master those skills, including seeking mutual cooperation, to negotiate Brazil nut supply.

The security of being able to rely on habilito ensures a proper organization of the early stages of Brazil nut harvesting. This is especially the case in remote communities. One month before the start of the Brazil nut harvest, forest dwellers must clear trails, repair roads and fix temporary storage facilities, activities that require at least one month on average (Interviews, 2009). If peasants would have to assure funds for the harvest without resorting to habilito, the opportunities for exploiting Brazil nuts would decrease substantially. Forest dwellers are not eligible for bank loans, and even if they were, it would take a prohibitively amounts of time and resources to negotiate such loans. In addition to pre-harvest investment, habilito greatly facilitates continued Brazil nut collection. The Brazil nut harvest demands for extended stays in the forest. When daily necessities are exhausted, Brazil nut collectors only make a short trip to restock from the trader, without worry of having to find another source of supply.

Once Brazil nut collection has finished the collector faces the challenge of moving his product to any Brazil nut company located in the regional towns. In riverside communities the movement of 150 boxes of Brazil nut of $25 \mathrm{~kg}$ might cost about \$US 700. With the price of \$US 17 per box in 2009 , this leaves a positive balance of \$US 1,850. The cost of taking the product out of the forest to the factory is approximately 27 percent of its total value. Because the collector delivers the Brazil nuts to the trader, he does not have to find resources to pay for transportation.

\section{DISCUSSION}

Our investigation demonstrates how an anachronistic mechanism of debt-peonage can - under certain circumstances - develop into an economic instrument that plays an essential role in an economic sector that has adapted to new political, social and economic realities. Worldwide, evidence exists on how debt peonage has evolved from a mechanism of social submission to a mechanism that is used in transactions under an economic rationality where partners need to 
determine priorities and needs, in order to capture benefits that they are seeking (Barham and Coomes 1994a, 1994b, 1994c, Gild 2006, Knight 1986, Washbrook 2006, Weinstein 1986). In all the cases studied these changes resulted from strategies of adjustment to changes in economic factors that connected the various actors through labor and other productive relations.

Nevertheless, in all the same cases to some degree and during variable periods, some elements of the mechanism's original exploitative nature persisted. This can be attributed to economic elite, mostly former patrons, who continue to use habilito to further its own interests. The more resource-endowed and powerful actors continue to seek hegemony of the productive chain in which they participate.

According to our research, in the northern Bolivian Amazon property rights over land and the exclusive right to decide over the use of valuable forest resources triggered transcendental changes in the balance of power among actors linked to the former modality of debt-peonage (Cano 2012). In spite of the social tensions at the onset of these changes, a certain degree of awareness was reached among actors with regard to their comparative advantages, stimulating a conduct of cooperation to preserve the new niches of power and assure access to valuable resources. A clear evidence of this is the reconfiguration of rights among on the one hand former patrons, traders and businessmen who control the means of production and on the other, rural communities who control the resources. The former labor relationships that marked the pre reform forest product sectors in northern Bolivia have become a commercial, c.q. capitalist relationship adapted to the limits of access and use of forest products.

The new conditions under which habilito is applied in northern Bolivia have modified the social, economic and labor relations. Until the recent changes in northern Bolivia habilito was mainly used to assure the supply of labor necessary for harvesting rubber and Brazil nuts (Bojanic 2001). Nowadays, the main item that is negotiated is the valuable forest resource that some control and want to sell, and others want to buy. Representatives of the various social sectors linked to the production chain, Brazil nut companies, the union of the Brazil nut collectors and representatives of the government, participate in negotiations of the Brazil nut price, which is done very early in the Brazil nut harvesting seasons to guarantee the transparency in prices and avoid tensions (Bojanic 2001). Traders in the field use this as guidance but adjust the price they pay, depending on their cost benefit assessment, however, without diverting too much from the official price.

Defaulting on the commercial obligations by one of the actors in a habilito agreement, which does happen frequently, can be understood from different perspectives: as immoral behaviour, as a legal infraction, or as a manifestation of the rights and power of each of the parties involved in the negotiation process. However, negotiations take place in an atmosphere of mutual tolerance, and not anymore as an imposition of the powerful patron towards the forest workers. But what explains this change in attitude among both groups of actors, for some towards a tolerance previously unacceptable while for others overstepping the limits of socially acceptable behaviour? Beside the spontaneous agreements that arose around the common interest in a particular resource, it seems that the opening of spaces of social individual and collective participation, as well as the exercise of the civil rights in the political arena as stipulated in the Popular Participation Law No 1551 the Municipalities Law No 2028, contributed to these changes. As a result of those changes, social conduct of the individual is not constrained 
anymore by former rules of submission and subordination, and this resulted in a new perception of social class, which is also reflected the negotiations of habilito.

In most of the cases studied, despite the changes in the balance of power, the perception of superiority of the patron continues in their relations with the labor class. The division between property rights over the resources and the means of production seems to reduce class differences when both have an interest to negotiate economic benefits from the use of forest resources. The result of this process is an increased respect between classes because of the links that they hold to their material means of production.

Key aspect in this discussion is the valuable forest resources themselves. Habilito is intrinsically tied to a great dependency on a particular resource, which partly allowed for the arbitrary control of the patrons over their laborers. Our research suggests that the mechanism can evolve towards more profitable scenarios for both actors, which is directly related to the productive diversification of actors in the production chain. However, it can be argued that the process of adaptation of habilito to a transformed Brazil nut production chain is conditioned by only one valuable forest product. Therefore, what can be expected in the future if this link changes radically due to a dramatic decrease of Brazil nut? The dependence on one valuable resource which is the mainstay of the local economy represents an important risk to the society of the region. The development of new productive activities could entail a new accommodation of the social, economic and power balance linked to the current productive activities based on the use of valuable forest resources. However, taken into account the evolution of habilito and the influence of legal reforms and economic changes in that process, a new relationship might develop, based on new forms of debt-peonage.

In our view, the study of the evolution of habilito in the northern Bolivian Amazon demonstrated the multiple alternatives of a mechanism that previously had the main objective to control and exploit a human group, towards a social mechanism of opportunities for economic benefit of the classes structured under a new social order. It is uncertain in what new ways the habilito system will develop in the future. Nevertheless, it is evident that the current productive structure and the economic possibilities for its users would be very different if the Brazil nut production chain were to collapse.

\section{CONCLUSION}

A salient characteristic of the end of the 20th century and of the present is the important advances achieved in the spheres of human rights, justice and social equity. The notable adherence of many countries to treaties and international agreements relative to these topics worldwide suggest that slavery, servitude and debt-peonage, as the most typical expressions of the feudal domination of the post-colonial period do not take place in this new age. Nevertheless, there exist multiple circumstances that yet allow the emergence of variants of this type of social relations, through which social exploitation with an economic purpose continue. In most cases the above mentioned variations are simply the result of choices made based on opportunity costs linked to social needs, labor and productive requirements. This is especially the case in developing countries with important structural productive and financial deficiencies, and even 
more so in remote regions where a weak presence of the state allows for little compliance of labor standards or similar regulations.

The debt-peonage modality can be considered as an extraordinary phenomenon worldwide, due to the exceptional characteristics that its process of evolution adopted in a short period of time. In northern Bolivia, some transcendental aspects that influenced this evolution were the normative changes linked to the civil condition and readdressing of land property rights and access to natural resources in favour of rural populations. The processes unleashed by these changes concerned the former patron relations and they motivated the emergency of more equitable commercial links, easier access to work capital and the specialization of every social sector within the most important production chain of the region. The mechanism adapted in tandem with shifts to relative social tolerance among actors linked to the resources of interest, but in a new context of proprietary rights. This fact suggests the prevalence of an economic rationality between actors valuing the benefit of decentralizing the production chain on the basis of its respective costs of production. 


\section{References}

Abercrombie, N., and Turner, S.B. (1978). The Dominant Ideology Thesis. The British Journal of Sociology 29: 149-170.

Alier, J.M. (1977). Relations of Production in Andean Haciendas: Peru. In Duncan, K., and Rutledge, I. (eds.), Land and Labor in Latin America, Cambridge University Press, Cambridge, pp. 141-163.

Assies, W. (1997). Muchas Cáscaras y Pocas Nueces: Extracción y Desarrollo Sustentable en la Amazonía. Debate Agrario: Análisis y Alternativas 26: 46-57.

Assies, W. (2002). From Rubber Estate to Simple Commodity Production: Agrarian Struggles in the North Bolivian Amazon. Journal of Peasant Studies 29: 83 - 130.

Bakx, K. (1988). From Proletarian to Peasant: Rural Transformation in the State of Acre, 18701986. The Journal of Development Studies 24: 141-160.

Bales, K. (2000). Expendable People: Slavery in the Age of Globalization. Journal of International Affairs 53: 461-484.

Barham, B., and O. Coomes. (1994a). The Amazon Rubber Boom: Labor Control, Resistance, and Failed Plantation development Revisited. The Hispanic American Historical Review 74: 231-257.

Barham, B., and O. Coomes. (1994b). Wild Rubber: Industrial Organization and the Microeconomics of Extraction during the Amazon Rubber Boom (1860 - 1920). Journal of Latin American Studies 26: 37-72.

Barham, B., and O. Coomes. (1994c). Reinterpreting the Amazon Rubber Boom: Investment, the State and Dutch Disease. Latin America Research Review 29: 73-109.

Barham, B., and O. Coomes. (1997). Prosperity's Promise: The Amazon Rubber Boom and Distorted Economic Development. The Hispanic American Historical Review 77: 749-751.

Barzel, Y. (1989). Economic Analysis of Property Rights, Cambridge University Press, Cambridge.

Bauer, J.A. (1979). Rural Workers in Spanish America: Problems of Peonage and Oppression. The Hispanic American Historical Review 59: 34-63.

Bhandari, S.( 2009). From Slavery to Debt-Bondage: Two Centuries of Exploitation in India. Mainstream 47: 33, 31.

Bojanic, A. (2001). Balance is Beautiful: Assessing Sustainable Development in the Rain Forests of the Bolivian Amazon. PhD dissertation, PROMAB - Utrecht University, Utrecht.

Burberi, M. (2007). Contemporary Forms of Enslavement: Slavery in Brazil. University of Florence.

Da Cunha, Euclides (1957). Rebellion in the Backlands. University Of Chicago Press, Chicago.

De Jong, W., Cano, W., Zenteno, M and Soriano, M. (forthcoming). Illegal Logging and Bolivia's Domestic Markets: The Legally Allowable versus the Informally Practicable

De Jong, W., Ruiz, S., and Becker, M. (2006). Conflicts and Communal Forest Management in Northern Bolivia. Forest Policy and Economics 8: 447-457.

Del Pilar-Gamarra, M. (2007). Amazonía Norte de Bolivia. Economía Gomera. Bases económicas de un poder regional - La Casa Suárez (Northern Bolivian Amazon. Rubber Economy. Economic Basis of Regional Power - The Suarez House). La Paz, CIMA press, Bolivia. 
DHV Consultants. (1993). Desarrollo de la Amazonía Boliviana: de la Actividad Extractiva hacia un Desarrollo Integral Sostenible (Development of Bolivian Amazon: From Extractive Activity to a Comprehensive Sustainable Development). La Paz, DHV press, Bolivia

Dore, E. (2003). Debt Peonage in Granada, Nicaragua 1870 - 1930: Labor in a Non-capitalist Transition. Hispanic American Historical Review 83: 521-559.

Dore, E. (2006). Myths of Modernity: Peonage and Patriarchy in Nicaragua. Durham, NC: Duke University Press.

Fifer, V. (1970). The Empire Builders: A History of the Bolivian Rubber Boom and the Rise of the House of Suarez. Journal of Latin American Studies 2: 113-146.

Fuentes, D. , R. Haches, R. Maldonado, M. Albornoz, P. Cronkleton, W. de Jong, Michel Becker (2005). Pobreza, descentralización y bosque en la Amazonia Boliviana. Bogor, Indonesia, CIFOR.

Henkemans, A.B. (2000). Social Fencing: Forest Dwellers and Control of Natural Resources in the Northern Bolivian Amazon. In Zoomers, A., and van der Haar, G. (eds.), Regulating Land Tenure under Post-Liberalism: Land Policy in Latin America, Amsterdam: KIT Press. pp. 123-145.

Henkemans, A (2001). Tranquilidad and Hardship in the Forest. Livelihoods and Perceptions of Camba Forest Dwellers in the Northern Bolivian Amazon. PhD dissertation, PROMAB Utrecht University, Utrecht.

Instituto Nacional de Estadísticas de Bolivia. (2007). Proyección de Población por Provincia y Sección de Provincia para el año 2007. http://. (accessed 20 August 2010)

Klein, H.S. (1969). Parties and Political Change in Bolivia 1880 - 1952. Cambridge University Press, Cambridge.

Knight, A. (1986). What was it and why was it? Journal of American Studies 18: 41-74.

Knight, A. (1988). Debt Bondage in Latin America. In Archer, L. (ed), Slavery and Other Forms of Unfree Labor, London: Routledge press, pp. 102-117.

Knowlton, C.S. (1962). Patron-Peon Pattern among the Spanish Americans of New Mexico. New Mexico Highlands University 41: 12-17.

Bolivian National Congress. (1996). Forestry Law No 1700. Ministerial Resolution $\mathrm{N}^{\circ} 131 / 97$ Special Regulations of Clearings. Bolivia, Gaceta Oficial del Estado press.

Lyons, B.J. (2006). Remembering the Hacienda: Religion, Authority, and Social Change in Highland Ecuador. Austin, University of Texas Press.

Marx, K. (1847). Wage Labor and Capital. http://www.marxists.org/archive/marx/works/1847/wage-labor/index.htm (accessed 3 September 2010).

McDonald, F., and McWhiney, G. (1980). The South from Self-Sufficiency to Peonage: An Interpretation. The American Historical Review 85: 1095-1118.

Meyers, A.D., and Carlson, D.L. (2002). Peonage, Power Relations, and the built Environment at Hacienda Tabi, Yucatan, Mexico, International Journal of Historical Archaeology 6: 225252.

Pacheco, P. (1992). Integración Económica y Fragmentación Social: El Itinerario de las Barracas en la Amazonia Boliviana (Economic Integration and Social Fragmentation: The Itinerary of Barracas in Bolivian Amazon). Bolivia, CEDLA press, Bolivia.

Pacheco, D. (2006). Manejo Forestal Comercial Comunitario en Propiedades Colectivas Indígenas de las Tierras Tropicales de Bolivia (Comercial Community Forest Management in 
Indigenous Collective Properties in Lowlands of Bolivia). Bolivia, CERES-IFRI press, Bolivia.

Parrish, C.T. (1982). Class Structure and Social Reproduction in New Spain/Mexico. Dialectical Anthropology 7: 137-153.

Ruiz, Antonio. (2005). Institutional Changes and Social Conflicts over Forest Use in the

Northern Bolivian Amazon. PhD dissertation, Freiburger Schriften zur Forst- und Umweltpolitik (10), Freiburg, Germany.

Rutledge, I. (1975). Plantations and Peasants in Northern Argentina: The Sugar Cane Industry of Salta and Jujuy, 1930 - 1943. In Rock, D. (ed), Argentina in The Twentieth Century, Gerald Duckworth \& Co. Ltd. press. pp. 88-113.

Stackley, P. (1999). Slavery in the Modern Era. World Socialist Web Site. http://www.wsws.org/articles/1999/sep1999/slav-s09.shtml (accessed 15 September 2010)

Stoian, D. (2000). Shifts in Forest Product Extraction: The Post-Rubber era in the Bolivian Amazon. International Tree Crops Journal 10: 277-297.

Stoian, D. (2006). La Economía Extractivista de la Amazonía Norte de Bolivia. CIFOR, Bogor, Indonesia.

Stoian, D., and Henkemans, A. (2000). Between Extractivism and Peasant Agriculture: Differentiation of Rural Settlements in the Bolivian Amazon. International Tree Crops Journal 10: 299-319.

Washbrook, S. (2006). Una Esclavitud Simulada: Debt Peonage in the State of Chiapas, Mexico, 1976-1911. Journal of Peasant Studies 33: 367-412.

Weinstein, B. (1986). The Persistence of Precapitalist Relations of Production in Tropical Export Economy: The Amazon Rubber Trade, 1850 - 1920. In Hanagan, M.,and Stephenson, C. (eds), Proletarians and Protest: The Roots of Class Formation in an Industrializing World. New York: Greenwood press.

Zenteno, M. (2012). Livelihood Strategies and Forest Dependency: New Insights from Bolivian Forest Communities. Utrecht University.

Zenteno, M. P. Zuidema, W. de Jong, R. Boot. (2013). Livelihood strategies and forest dependency: New insights from Bolivian forest communities. Forest Policy and Economics 26, $12-21$. 
Figure 1. New scheme of actors of habilito system.

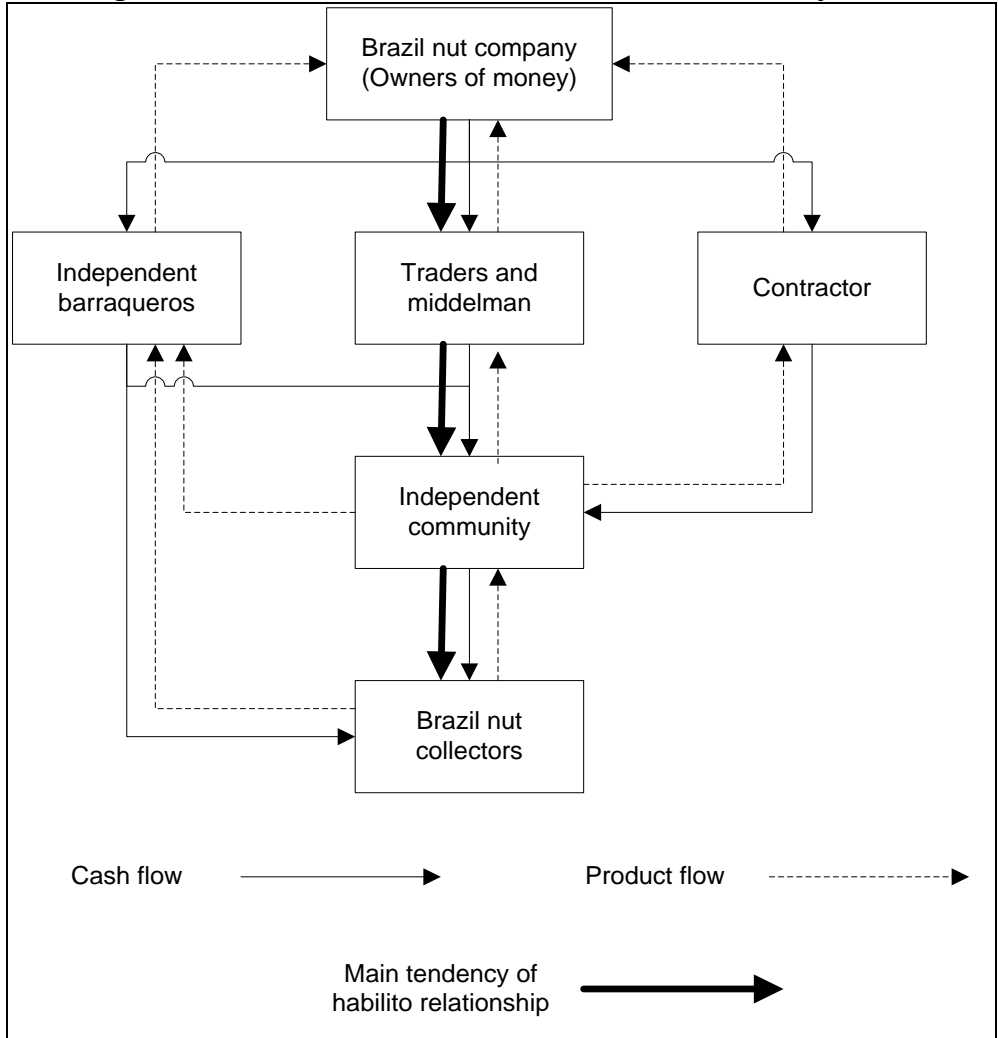




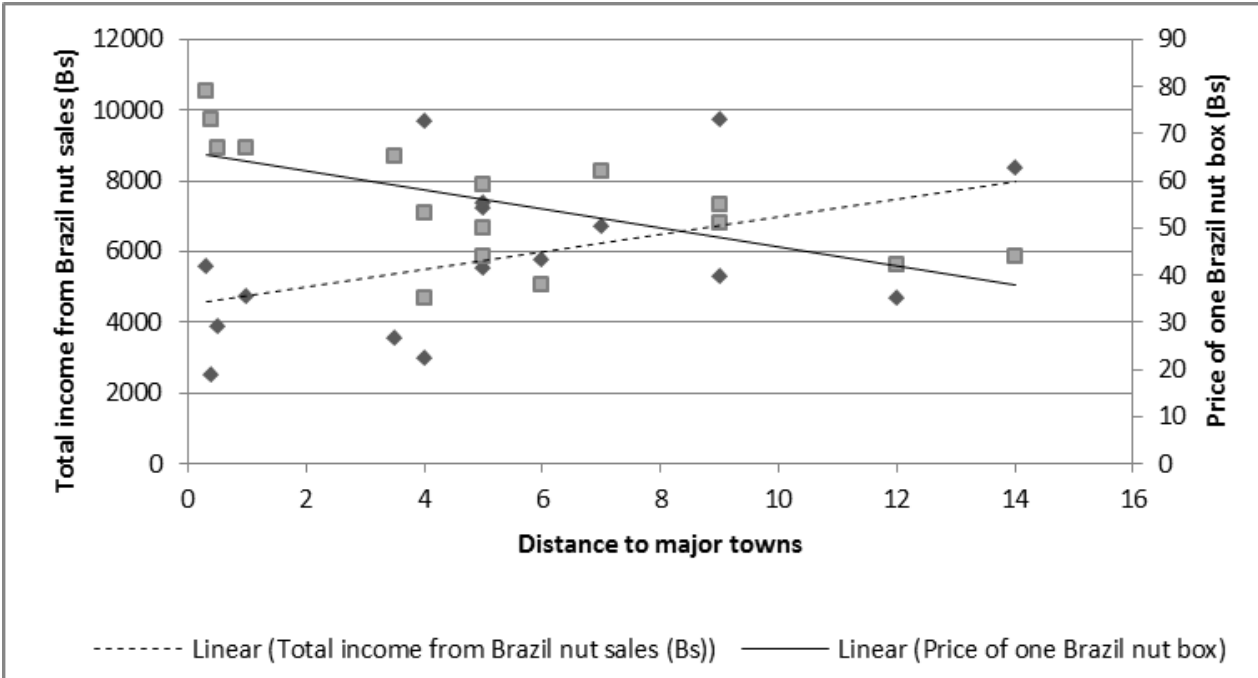

Figure 2. Variation in revenue from Brazil nut sales related to community access.

(Lines are based on data regressions) 
Table 1

Economic and productive differences between people depending and not-depending on the habilito. Statistical test results (p-values) are based on two-sample t-tests.

\begin{tabular}{|l|c|c|c|c|}
\hline \multicolumn{1}{|c|}{ Parameters } & $\begin{array}{c}\text { Sample without } \\
\text { habilito } \\
\text { (A) }\end{array}$ & $\begin{array}{c}\text { Sample with } \\
\text { habilito } \\
\text { (B) }\end{array}$ & $\begin{array}{c}\text { Percentage } \\
\text { difference, } \\
\text { (B-A)/A*100 } \\
\text { of B with } \\
\text { respect to A }\end{array}$ & $p$ \\
\hline $\begin{array}{l}\text { Total revenue from Brazil nut } \\
\text { sales (Bs.) }\end{array}$ & 4020 & 6510 & 38 & $<0.001$ \\
\hline $\begin{array}{l}\text { Number of harvested Brazil } \\
\text { nut boxes per family }\end{array}$ & 70 & 123 & 43 & $<0.001$ \\
\hline $\begin{array}{l}\text { Price received per Brazil nut } \\
\text { box, 2008 (Bs.) }\end{array}$ & 57.4 & 52.3 & -9 & $<0.01$ \\
\hline $\begin{array}{l}\text { Effective days of Brazil nut } \\
\text { harvesting, 2008 }\end{array}$ & 29 & 38 & 23 & $<0.001$ \\
\hline $\begin{array}{l}\text { Agricultural crops, 2008 - } \\
\text { 2009 (has) }\end{array}$ & 2.07 & 1.62 & 31 & $<0.001$ \\
\hline Rice bought, 2008 (arroba) & 8.2 & 12 & 57 & $<0.05$ \\
\hline $\begin{array}{l}\text { Food used for animals } \\
\text { (arroba) }\end{array}$ & 47 & 20 & 56 & $<0.05$ \\
\hline Number of pigs per family & 1.63 & 0.71 & & $\mathrm{n} . \mathrm{s}$ \\
\hline $\begin{array}{l}\text { Benefits from timber sales } \\
\text { from forest management } \\
\text { plans (Percentage of familiar } \\
\text { total income) }\end{array}$ & 14.7 & 19.0 & & \\
\hline
\end{tabular}

Source: Modified based on Zenteno (2012). *About $15 \mathrm{~kg}$. 
Table 2: Classification of interviewees based on their capacity to collect Brazil nuts

\begin{tabular}{|c|c|}
\hline $\begin{array}{c}\text { Type of Brazil nut } \\
\text { producer }\end{array}$ & $\begin{array}{c}\text { Average Brazil nut } \\
\text { income (Bs) }\end{array}$ \\
\hline Large & 32,300 \\
\hline Medium & 13,400 \\
\hline Small & 3,800 \\
\hline
\end{tabular}

Source: Based on Zenteno (2012) 